\title{
Analysis of the earnings management methods of China's electric power companies based on modified Jones model
}

With the constant revision of accounting standards, the earnings management methods are constantly changed and innovated in order to achieve the purpose of beautifying the statements and manipulating profits. This paper took the electricity listed companies as the research object, selected the financial data of 52 listed companies in the Shanghai Stock Exchange and the Shenzhen Stock Exchange from 2014 to 2016 as the sample, and employed the SPSS statistics software to analyze the earnings management methods of the listed companies in the electric power industry and to draw the conclusions through empirical research. Based on the preliminary statistical analysis of the earnings management methods of listed companies in the electric power industry, this paper used the modified Jones model to verify the empirical analysis. The main conclusions of this paper are as follows: There is a positive linear relationship between fixed assets management, assets impairment management and discretional accruals of the listed companies in the electric power industry. The degree of its influence is more obvious and stable than that of other earnings management methods, and passed the significance test. The collinear diagnostics can also prove a more reasonable correlation among the variables, indicating that the results obtained from the modified Jones model is more significant.

Keywords: Listed companies in electric power industry, earnings management methods, modified Jones model.

\section{0 Introduction}

$\mathrm{T}$ The electric power industry is responsible for the production and transmission of electricity for the national economy, its earnings management plays a decisive role in the healthy development of the national economy and the capital market, moreover, the reliability and relevance of the earnings information has also become the focus of the stakeholders. As a representative part of the

Messrs. Zhibin Liu, Xiaoning Li, Department of Economics and Management, North China Electric Power University, Baoding, and NianXie, Guodian Quanzhou Thermal Power Co., Ltd, Quanzhou, China. electric power industry, its earnings management methods have distinct characteristics of the industry and incorporate with more political factors. This paper will start from this background, analyze the earnings management methods of electricity listed companies, study the preference accounting subjects and specific accounting methods in earnings management, make empirical tests on the analysis results, and put forward the corresponding improvement and management measures, providing more reference information and data for earnings management in the electric power industry. Presently, there is a total of 56 electricity companies listed in China's A stock market, which can basically represent the overall situation of the electric power industry. The major listed companies of the five power generation group are shown in Table 1.

TABLE 1: Listed COMPANIES OF FIVE POWER GENERATION GROUP

\begin{tabular}{ll} 
Generation group & Listed companies \\
\hline Huaneng & $\begin{array}{l}\text { Huanengguoji, Neimenghuadian, } \\
\text { Huanengxinnengyuan } \\
\text { Guodian }\end{array}$ \\
& $\begin{array}{l}\text { Puodiandianli, Changyuandianli, Yinglite, } \\
\text { Huadiannengyuan, Huadianguoji, } \\
\text { Quadian }\end{array}$ \\
Datang & $\begin{array}{l}\text { Datangfadiandianli, Guodiannanzi, Jinshangufen } \\
\text { Zhanghaidianli, Guotoudianli, Jidiangufen, } \\
\text { Zhongdiantou }\end{array}$ \\
& zhangzedianli \\
\hline
\end{tabular}

Earnings management has always been one of the hot issues in the accounting academic circles at home and abroad, and there are many different views on the definition of its concept. American scholar Scott [1] believed that earnings management refers to an act that the companies select and change the accounting policy under the accounting laws and regulations as a basis for the financial statements, and use it to influence the profits in order to obtain more business interests or personal interests. This is basically consistent with the definition of earnings management by Chinese scholars [2-3]. While Schipper [4] considered that earnings management is that the company's managers to interfere with the disclosure of financial statements with a purpose of 
misleading the stakeholders' judgments to the company's actual financial situation. With the gradual advancement of this issue in the accounting profession, the more authoritative definition is that earnings management refers to the process of changing the relevant information of the enterprise profit and making accounting decisions when the report is issued in order to influence the internal and external stakeholders' knowledge of the profitability and development prospects of the company.

So far, there are a lot of literatures at home and abroad that have studied the motivation of earnings management, they are mainly as the following: Capital market motivation, contractual motivation and regulatory motivation. As far as the capital market motivation is concerned, on the one hand, the management of the company will conduct earnings management when the equity is issued or when they want to meet some special criteria, so that they can achieve the purpose of preventing investors from disappointment [5]. On the other hand, the company operator will manipulate the profits when the company initiates the first IPO or issues new stocks in order to influence the decision of the external investors [6-7]. The contractual motivation is mainly related to the debt contract and the internal transaction, which will urge the management to improve the level of earnings. Moreover, when the company's financial situation is good, managers can not only get the bonus related to the earnings, but also can enhance their work security [8-9], which promote the management of the company to carry out earnings management. Finally, regulatory motivation is due to the fact that the financial data disclosed by the company is related to public safety to some extent, especially in the pharmaceutical industry and the crude oil industry. In addition, the government's allowance and potential benefits may induce the management of the company to manipulate the earnings.

There are two main ways to conduct earnings management by company managers: Accrual earnings management and real earnings management. Accrual earnings management refers to the managers of corporate, in the case of accounting standards permitting, flexibly use the accounting policies and accounting methods to manage corporate earnings in order to achieve the purpose of hiding the company's actual financial situation [10-13]. It includes the use of accounting policies for earnings management, the use of accounting estimates for earnings management and the use of income and expenditure recognition to conduct earnings management [14-15]. Real earnings management refers to the management of the company influence the cash flow of enterprises through real accounting activities, thus affecting the profits of enterprises to complete the manipulation of corporate profits, and ultimately affect the disclosure of financial statements, the main methods include related party transactions, assets or debt restructuring and fictitious transactions or assets.

In general, the current research literature on earnings management is mostly theoretical analysis, while there is less paper which combined with empirical research. This paper combined the relevant theory with the empirical analysis, and used the modified Jones model [16-17] to analyze the earnings management methods of listed companies in China's electric power industry and draw the conclusion.

\subsection{Statistical analyses of the main methods of earnings management of listed companies in electric power industry}

This section selects 52 electricity listed companies in Shanghai Stock Exchange and Shenzhen Stock Exchange as the research subject and draws detailed information of fixed assets depreciation and assets impairment in the annual financial statements for the three years from 2014 to 2016 as a data sample for statistical analysis. All the annual financial statements information of listed companies in this paper is derived from Sina Finance.

\subsection{EARNINGS MANAGEMENT OF FIXED ASSETS}

After analyzing and processing the depreciation expenses of fixed assets in the financial statements of 52 electricity listed companies from 2014 to 2016, we can get the relevant information on the change rate of depreciation expense, and group the relevant data in statistics, the results are shown in Tables 2 and 3 .

From the above summary of the situation, most of the change rates of depreciation expenses are at the range of $10 \%$ to $20 \%$, and it is also normal that fluctuated from 0 to $10 \%$. Among the top five power generation groups, the listed companies who control the Datang, Guodian, Huadian and

TABLe 2: Changes of DePReCiation EXPENSES IN 2016

\begin{tabular}{ccl}
\hline $\begin{array}{c}\text { Change rate of } \\
\text { depreciation expense }\end{array}$ & Frequency & $\begin{array}{l}\text { Typical } \\
\text { business }\end{array}$ \\
\hline$<0$ & 1 & $\begin{array}{l}\text { Dongfangnengyuan } \\
\text { Wannengdianli, Changyuandianli, Huanengguoji, Zhenengdianli, Shennenggufen, } \\
\text { Guotoudianli }\end{array}$ \\
$0-10 \%$ & 16 & $\begin{array}{l}\text { Datangfadian, Guodiandianli, Huadianguoji, YuedianliA, Shanghaidianli, Zhangzedianli } \\
\text { Baoxinnengyuan, Gannenggufen, Qianyuandianli, Lianmeikonggu, Jinshangufen, } \\
\text { Ningboredian }\end{array}$ \\
$10 \%-20 \%$ & 27 & Hailianxun, Tianhaojieneng \\
$20 \%-30 \%$ & 6 &
\end{tabular}


TABle 3: Changes OF DEPRECIATION EXPENSES IN 2015

\begin{tabular}{|c|c|c|}
\hline $\begin{array}{l}\text { Change rate of } \\
\text { depreciation expense }\end{array}$ & Frequency & $\begin{array}{l}\text { Typical } \\
\text { business }\end{array}$ \\
\hline$<0$ & 2 & Hunanfazhan, Changyuandianli \\
\hline $0-10 \%$ & 15 & $\begin{array}{l}\text { Huanengguoji, Zhenengdianli, Guiguandianli, Tongbaonengyuan, Mindongdianli, } \\
\text { Shennandian A }\end{array}$ \\
\hline $10 \%-20 \%$ & 25 & Yuedianli A, Shanghaidianli, Sanxiadianli, Huadiannengyuan, Guodiandianli, Datangfadian \\
\hline $20 \%-30 \%$ & 4 & Changjiangdianli, Jinshangufen, Lianmeikonggu, Jidiangufen \\
\hline$>30 \%$ & 6 & Baoxinnengyuan, Hailianxun, Zhangzedianli, Tianhaojieneng, Jingnengdianli, Ningboredian \\
\hline
\end{tabular}

Zhongdiantou have a $10 \%$ to $20 \%$ rate of change in depreciation expenses for two consecutive years, reflecting their relatively stable depreciation policy of fixed assets; Huaneng has been in the range of 0 to $10 \%$, the rate of change is lower, indicating that the fixed assets basically has no earnings management trace on the operation. Overall, the fluctuations of $0 \%$ to $20 \%$ are basically normal depreciation of fixed assets; if the rate of change is less than 0 , it indicates that the depreciation expenses of fixed assets withdrawn in the current year is negative, which may be caused by a fixed assets group with a large scrapping amount; companies with a $20 \%$ to $30 \%$ rate of change are relatively small, but the companies with the rate of change greater than $30 \%$ is the least among the overall samples. The rate of change in the depreciation expenses of fixed assets over 30\% means that the amount of depreciation accrued in that year exceeds one third of the total amount than that of last year. Even if it is caused by the normal changes of accounting policies or the purchase of new fixed assets, there is still some suspicion of earnings management and the possibility of tax avoidance by reducing the profits. The following is a specific analysis for Tianhaojieneng which has the rate of change more than $30 \%$ for two consecutive years.

The rate of changes in depreciation expenses for the Tianhaojieneng in 2016 and 2015 were $32.49 \%$ and $58.78 \%$ respectively. The rate of change in 2015 was close to $60 \%$, which was especially abnormal. By checking its annual financial statements for 2015, it can be seen that the accumulated depreciation book balance of the company at the beginning of the period was 84,289,977.69 Yuan, and it was as high as $133,833,994.58$ Yuan in the end of 2015, of which the newly added depreciation amount was 49,636,057.02 Yuan and decreased by 96,425.61 Yuan at the current period, which illustrated that the current depreciation amount exceeds half of accumulated depreciation at the beginning of the period. However, the company attached an additional note stating when explaining the accounting policies on fixed assets: For the fixed assets formed by the construction of waste heat power generation projects, the depreciation shall be calculated according to the shorter of the actual using life and the remaining life which stipulated in the agreement; the residual value of fixed assets operated by the cooperating party after the expiration of the operating period shall not be salvaged; after the expiration of the contract, the fixed assets operated by the cooperating party shall be treated as gifts. In the accounting treatment of this fixed assets, it is obvious that the company set its estimated net salvage value as zero, which was greatly increasing the depreciation expenses for each accounting period. Moreover, the original book value of fixed assets was 777,848,503.68 Yuan at the beginning of the period, and the value of the fixed assets transferred from construction in progress was 263,763,368.45 Yuan in the current period, nearly one third of the original value. The large-scale increase in fixed assets and depreciation expense has resulted in the increase of 58\% in cumulative depreciation compared to 2016. This unusually high growth and the more vague interpretation illustrate the potential for earnings management of the company in this area of fixed assets.

Based on the above analysis, it can be seen that most of the electricity listed companies are fairly standardized to deal with the depreciation expenses of fixed assets, and the depreciation policies are relatively stable with a normal range of depreciation expenses each period, indicating no sign for the existence of earnings management. However, there are also a few listed companies that have a sharp fluctuation in depreciation expenses for two consecutive years. The companies explained vaguely about the related accounting policies and accounting estimates of fixed assets, and the specific reasons for the increase and decrease of depreciation expenses were difficult to excavate in the financial statements. These companies, to some extent, have signs of earnings management in the fixed assets and deserve the attention of investors and relevant departments. Overall, the electricity listed companies tend to use the method of depreciation expense adjustment to achieve the purpose of reducing the current profits in order to win the target of earnings management.

\subsection{EARNINGS MANAGEMENT OF ASSET IMPAIRMENT}

Due to the small or no impairment provision of noncurrent assets in the selected samples, this section mainly analyzed two items of bad debt provision and the provision for inventory, and the impairment provision of non-current assets was not considered temporarily. Based on a collection and process of the annual statements of the listed companies in 2014-2016, we get the annual ratio of bad debt provision to 
receivables (mainly refers to accounts receivable and other receivables) and the annual ratio of the inventory provision to total inventory for 3 years. The details are shown in Tables 4 to 9 .
The following can be seen from the above summary results:

(1) The ratio of bad debt provision in electricity listed

TABLE 4: BAD DEBT PROVISION IN 2016

\begin{tabular}{|c|c|c|}
\hline $\begin{array}{l}\text { Ratio of bad debt } \\
\text { provision to } \\
\text { receivables }\end{array}$ & Frequency & Typical business \\
\hline$=0$ & 14 & ShennandianA, Xinnengtaishan, Gannenggufen, Hailianxun, Guangzhoufazhan, Lianmeikonggu \\
\hline $0-2 \%$ & 11 & Changyuandianli, Changchunjingkai, Jinshangufen, Shennenggufen, Guotoudianli \\
\hline $2 \%-4 \%$ & 15 & Fulingdianli, Guodiandianli, Huadianguoji, YuedianliA, Zhangzedianli, Chuantounengyuan \\
\hline $4 \%-5 \%$ & 7 & Baoxinnengyuan, Qianyuandianli, Jinshangufen, Shanghaidianli, Tongbaonengyuan \\
\hline$>5 \%$ & 5 & Guidongdianli, Mingxingdianli, Huayindianli, Mindongdianli, Wannengdianli \\
\hline & & TABLE 5: BAD DEBT PROVISION IN 2015 \\
\hline $\begin{array}{l}\text { Ratio of bad debt } \\
\text { provision to } \\
\text { receivables }\end{array}$ & Frequency & Typical business \\
\hline$=0$ & 1 & Ningboredian \\
\hline $0-2 \%$ & 18 & Hunanfazhan, Changyuandianli, Guiguandianli, Tongbaonengyuan, Mindongdianli, ShennandianA \\
\hline $2 \%-4 \%$ & 21 & YuedianliA, Shanghaidianli, Sanxiashuili, Minjiangshuidian, Guodiandianli, Datangfadian \\
\hline $4 \%-5 \%$ & 9 & Changjiangdianli, Jinshangufen, Lianmeikonggu, Jidiangufen, Baoxinnengyuan, Hailianxun \\
\hline$>5 \%$ & 4 & Zhangzedianli, Tianhaojieneng, Jingnengdianli, Ningboredian \\
\hline
\end{tabular}

TABLE 6: BAD DEBT PROVISION IN 2014

\begin{tabular}{ccl}
\hline $\begin{array}{c}\text { Ratio of bad debt } \\
\text { provision to } \\
\text { receivables }\end{array}$ & Frequency & Typical business \\
\hline$=0$ & 1 & Tianhaojieneng \\
$0-2 \%$ & 15 & Baoxinnengyuan, Gannenggufen, Qianyuandianli, Lianmeikonggu, Jinshangufen, Ningboredian \\
$2 \%-4 \%$ & 26 & Jingnengdianli, Huayindianli, Hongyangnengyuan, Chendianguoji, Shanghaidianli, Wenshandianli \\
$4 \%-5 \%$ & 8 & Binhainengyuan, Guangzhoufazhan, Kaididianli, Xinnengtaishan, YuedianliA \\
$>5 \%$ & 2 & Mingxingdianli, Xichangdianli \\
\end{tabular}

TABLe 7: Provision for INVENTORY IN 2016

\begin{tabular}{ccl}
\hline $\begin{array}{c}\text { Ratioof inventory } \\
\text { provision to total } \\
\text { inventory }\end{array}$ & Frequency & Typical business \\
\hline$=0$ & 15 & Changjiangdianli, Tongbaonengyuan, Shennenggufen, Jinshangufen, Minjiangshuidian \\
$0-10 \%$ & 26 & Tianhaojieneng, Mindongdianli, Gannenggufen, Xinnengtaishan, Wannengdianli, SuihengyunA \\
$10 \%-20 \%$ & 7 & Baoxinnengyuan, Zhangzedianli, Dongfangnengyuan, Qianyuandianli, Guangzhoufazhan \\
$>20 \%$ & 4 & Huadianguoji, Huayindianli, Guotoudianli, Shaonenggufen
\end{tabular}

TABle 8: Provision for INVEnTory IN 2015

\begin{tabular}{ccl}
\hline $\begin{array}{c}\text { Ratioof inventory } \\
\text { provision to total } \\
\text { inventory }\end{array}$ & Frequency & Typical business \\
\hline$=0$ & 16 & Lianmeikonggu, Jinshangufen, Jingnengdianli, Huayindianli, Chendianguoji \\
$0-10 \%$ & 20 & Meiyanjixiang, Tongbaonengyuan, Huadiannengyuan, Fulingdianli, Guiguandianli, Sanxiashuili \\
$10 \%-20 \%$ & 13 & Huadianguoji, Huanengguoji, Yunengkonggu, Dongfangnengyuan, Jidiangufen, Xinnengtaishan \\
$>20 \%$ & 3 & Neimenghuadian, Guotoudianli, ShennandianA
\end{tabular}




\begin{tabular}{ccl}
\hline $\begin{array}{c}\text { Ratioof inventory } \\
\text { provision to total } \\
\text { inventory }\end{array}$ & Frequency & Typical business \\
\hline$=0$ & 18 & Shaonenggufen, SuihengyunA, Wannengdianli, Baoxinnengyuan \\
$0-10 \%$ & 26 & Gannenggufen, Qianyuandianli, Huadianguoji, Changchunjingkai, Tianfunengyuan, Hongyangnengyuan \\
$10 \%-20 \%$ & 6 & Changjiangdianli, Wenshandianli, Neimenghuadian, Chuantounengyuan, Shennenggufen \\
$>20 \%$ & 2 & Guidongdianli, Shanghaidianli \\
\hline
\end{tabular}

companies is mostly in the range of 0 to $4 \%$, relatively small in the range of $4 \%$ to $5 \%$. However, in some years, the company increased the ratio of bad debt provision to a range of $4 \%$ and $5 \%$ due to operating reasons, which is also a normal and acceptable range. While the number of enterprises with more than $5 \%$ of bad debt provision has been significantly reduced for three consecutive years, indicating that the 5\% standard can be roughly regarded as the critical judgment point for whether the ratio of bad debt provision is reasonable or not. If the company exceeds this standard, it indicates that the management of receivables needs to be strengthened, or the company faces another possibility of making earnings management by accruing bad debt provision.

(2) With regard to the provision for inventory, this provision is obviously less than the bad debt provision. On the one hand, due to the stricter mandatory requirements for inventory impairment testing and the detailed data on the cost and net realizable value required to achieve the corresponding standards, it is relatively more complicated to conduct earnings management with this method. On the other hand, when there is a need to reverse the impairment provision in subsequent accounting periods, it must also be reasonably adequately justified, which is not conducive to the adjustment of profits in companies that wish to conduct earnings management. Among the listed companies that accrued provisions for inventory, most of the companies had accrued proportion of provisions at the range of 0 to $20 \%$, of which the companies that of 0 to $10 \%$ were more concentrated. While companies with more than $20 \%$ of the accrued proportion decreased significantly, indicating that nearly one-fifth of the total inventories may be impaired. The indirect information passed to investors and creditors is that the company's product sales may not be good, or the company reduces profits by using inventory impairment to conduct the earnings management.

\subsection{Preliminary CONCLUSIONS}

This chapter summarized the detailed data of fixed assets depreciation and assets impairment provision in the annual financial statements of the 52 listed companies from 2014 to 2016 , and obtained the preliminary information about the two main earnings management methods of the electricity listed companies. Among them, with regard to the earnings management of fixed assets, the change rate of depreciation expense for most of the companies remains in the range of 0 to $30 \%$, companies exceeding this percentage have fewer samples. And through the specific case analysis of Tianhaojieneng, it is preliminarily determined that such companies may have earnings management on the fixed assets, and tend to increase the depreciation expenses to reduce the profits. In respect of the earnings management of asset impairment, the majority of companies control the ratio of bad debt provision to receivables within 5\%, while the minority of that are more than 5\%. Comparatively speaking, the provision for inventory in the listed companies is less than the bad debt provision. Most of the companies that accrued provision for inventory have the accrued proportion of 0 to $30 \%$. The companies have the accrued proportion of more than $30 \%$ may be due to direct selling of products or the target of earnings management through inventory impairment. In general, enterprises that use various kinds of earnings management methods are the minority in the electricity listed enterprise groups, while they both use the two methods of fixed assets depreciation and asset impairment in varying degrees.

The above discussion is based on the preliminary statistical analysis of major earnings management methods of electricity listed companies. The empirical analysis and the relevant models will be employed to further test the statistical analysis results in this chapter, and the earnings management methods will be further discussed later.

\subsection{Empirical study on earnings management methods of electricity listed companies based on modified Jones model}

The metrology model of earnings management has always been one of the hot issues discussed by accounting circles at home and abroad. So far, the authoritative metrology model of earnings management is the modified Jones model. Since the parameters used in the cross-sectional Jones model are cross-sectional data rather than time-series data, it has no requirement on the length of time and is more convenient and flexible to use. This paper intends to employ the modified cross-sectional Jones model to carry out the empirical analysis of the earnings management methods of electricity listed companies.

\subsection{Hypothesis}

Based on the statistical analysis of the main methods of 
earnings management of listed companies in the electric power industry in the previous chapter, we can get a preliminary understanding of some characteristics of the earnings management. Combining with the characteristics of the electric power industry and the impact brought by promulgation of new accounting standards, this paper proposes the following two hypotheses:

Hypothesis 1: The electricity listed companies adjusted the depreciation expenses of fixed assets to reduce profits to achieve the target of earnings management.

Hypothesis 2: The electricity listed companies used the bad debt provision and provision for inventory to carry out earnings management.

\subsection{SAMPLE SELECTION}

This paper selected 52 electricity listed companies in Ashare as samples, analyzing the relevant data in the annual financial statements from 2014 to 2016 . All related financial information of listed companies is derived from Sina Finance, Shanghai Stock Exchange and the Shenzhen Stock Exchange.

\subsection{Metrology model}

\subsubsection{Measurement of earnings management}

\section{(1) Accrual earnings management}

The non-discretional accruals are derived from equation (1):

$$
\begin{aligned}
\frac{N D A_{i, t}}{A_{i, t-1}}= & \alpha_{1}\left(\frac{1}{A_{i, t-1}}\right)+\alpha_{2}\left(\frac{\Delta S A L E S_{i, t}}{A_{i, t-1}}\right) \\
& +\alpha_{3}\left(\frac{F A_{i, t}}{A_{i, t-1}}\right)+\alpha_{4}\left(\frac{I A_{i, t}}{A_{i, t-1}}\right)+\varepsilon_{i, t}
\end{aligned}
$$

Where $N D A_{i, t}$ is the total non-discretional accrual of company $i$ in year $t$. Its value is equal to the difference between operating profit and operating cash flows. Where $\triangle S A L E S_{i, t}$ is the change in the sales revenue of company $i$ in year $t$, which is equal to the difference of actual sales revenue of the company in year $t$ and that in year $t-1$. Where $F A_{i, t}$ is the original value of fixed assets of company $i$ in year $t$. Where $I A_{i, t}$ is the original value of intangible assets of company $i$ in year $t$. Where $A_{i, t-1}$ is the total assets of the company $i$ at the end of year $t-1$. Where $\varepsilon_{i, t}$ is the residual term.

The total accruals is given by equation (2):

$$
\frac{T A_{i, t}}{A_{i, t-1}}=\alpha_{1}\left(\frac{1}{A_{i, t-1}}\right)+\alpha_{2}\left(\frac{\Delta R E V_{i, t-1}}{A_{i, t-1}}\right)+\alpha_{3}\left(\frac{F A_{i, t}}{A_{i, t-1}}\right)+\varepsilon_{i, t} \ldots
$$

Where $T A_{i, t}$ is the net profit of company $i$ in year $t$. Where $\triangle R E V_{i, t-1}$ is the diffirence of prime operating revenue of company $i$ between the year $t$ and the year $t-1$.

Since the sum of non-discretional accruals $\left(N D A_{i, t}\right)$ and discretional accruals $\left(D A_{i, t}\right)$ is the total accruals, thus, after the $N D A_{i, t}$ and $T A_{i, t}$ are separately calculated, the absolute value of the difference between the two is the value of discretional accruals. The formula is as follows:

$$
D A_{i, t}=T A_{i, t}-N D A_{i, t}
$$

\section{(2) Real earnings management}

Real earnings management consists of three parts: discretionary operating cash flows, discretionary production costs and discretionary expenses. The metrology models are as follow:

The estimation model of expected operating cash flow is shown as formula (4):

$$
\frac{C F O_{i, t}}{A_{i, t-1}}=\alpha_{1}\left(\frac{1}{A_{i, t-1}}\right)+\alpha_{2}\left(\frac{\operatorname{SALES}_{i, t}}{A_{i, t-1}}\right)+\alpha_{3}\left(\frac{\Delta \operatorname{SALES}_{i, t}}{A_{i, t-1}}\right)+\varepsilon_{i, t} \ldots
$$

Where $C F O_{i, t}$ means the expected operating cash flows of business $i$ in year $t$. Where $S A L E S_{i, t}$ is the operating revenue of company $i$ in year $t$. The discretionary operating cash flows $\left(\mathrm{DCFO}_{i, t}\right)$ can be obtained using the actual operating cash flows of an enterprise minus the expectation. The enterprise is often to increase business income to improve profitability with this method. The earnings management method of sales control will make the company's actual operating cash flows lower than expected.

The estimation model of expected production cost is shown as formula (5):

$$
\begin{aligned}
\frac{P R O D_{i, t}}{A_{i, t-1}} & =\alpha_{1}\left(\frac{1}{A_{i, t-1}}\right)+\alpha_{2}\left(\frac{\text { SALES }_{i, t}}{A_{i, t-1}}\right) \\
& +\alpha_{3}\left(\frac{\Delta S A L E S_{i, t}}{A_{i, t-1}}\right)+\alpha_{4}\left(\frac{\Delta S A L E S_{i, t-1}}{A_{i, t-1}}\right)+\varepsilon_{i, t}
\end{aligned}
$$

Where $P R O D_{i, t}$ means the expected production costs of company $i$ in year $t$, which is the sum of sales costs and inventory changes. The discretionary production costs $\left(D P R O D_{i, t}\right)$ can be obtained using the actual production costs of an enterprise minus the expectation. The application of this method is usually reduced the sales costs to increase profits. The earnings management method of production control will make the company's actual production costs higher than expected.

The estimation model of expected expenses is shown as formula (6):

$$
\frac{\operatorname{DISEXP}_{i, t}}{A_{i, t-1}}=\alpha_{1}\left(\frac{1}{A_{i, t-1}}\right)+\alpha_{2}\left(\frac{\text { SALES }_{i, t-1}}{A_{i, t-1}}\right)+\varepsilon_{i, t}
$$

Where DISEXP ${ }_{i, t}$ means expected expenses of company $i$ in year $t$. The discretionary expenses $\left(D D I S E X P_{i, t}\right)$ can be obtained using the actual expenses of an enterprise minus the expectation. The model improves the performance of the company by reducing some of the expenses that do not generate revenues during the current period. The earnings management method of expenses control will make the company's actual expenses lower than expected.

Finally, the total of real earnings management is given by equation (7): 


$$
\operatorname{DREM}_{i, t}=\operatorname{DPROD}_{i, t}-\text { DCFO }_{i, t}-\text { DDISEXP }_{i, t} \quad \ldots 7
$$

3.3.2 Analysis model of earnings management methods in electricity listed companies

Based on the analysis of the above two models of accrual earnings management and real earnings management, combining with the characteristics of China's electric power industry, several financial indicators closely related to the electric power industry are introduced here: Fixed assets (FA), impairment of assets (IOA), investment income (IVT), operating cash flows (CFO), non-operating income and expenditure (NOI). Using the above indicators and the analysis in the previous section, this paper establishes a specific model to analyze the earnings management methods of listed companies in electric power industry. This model basically covers the two main methods of fixed assets earnings management and asset impairment earnings management. Of course, the substitution of relevant indicators will also reflect the impact of some other earnings management methods on the final variable. Here, we mainly focus on the two earnings management methods of fixed assets and asset impairment. In summary, the model of discretional accruals of electricity listed companies is shown in formula (8):

$$
D A_{i, t}=\alpha_{0}+\alpha_{1} F A+\alpha_{2} I O A+\alpha_{3} I V T+\alpha 4 \mathrm{CFO}+\alpha_{5} \mathrm{NOI}+\varepsilon_{\mathrm{i}, \mathrm{t}} \ldots
$$

\subsection{EMPIRICAL TEST}

\subsubsection{Descriptive statistics analysis}

By substituting various financial indexes of electricity listed companies into the model, we can get the descriptive statistics corresponding to the discretional accruals of companies in different years. The results are shown in Table 10.

Table 10: Descriptive Statistics

\begin{tabular}{lccc}
\hline Statistics & DA in 2014 & DA in 2015 & DA in 2016 \\
\hline Mean & 0.041787 & 0.040265 & 0.039872 \\
Variance & 0.001108 & 0.000479 & 0.001391 \\
Standard deviation & 0.033285 & 0.021896 & 0.037291 \\
Maximum & 0.101259 & 0.086852 & 0.098237 \\
Minimum & -0.112562 & -0.098334 & -0.096875 \\
Summation & 0.902214 & 0.891238 & 0.998265 \\
\hline
\end{tabular}

\subsubsection{Regression analysis}

In this paper, we have a regression analysis to the aforementioned models of the earnings management methods with SPSS software, and calculate the corresponding parameter values of $\alpha_{0}, \alpha_{1}, \alpha_{2}, \alpha_{3}, \alpha_{4}, \alpha_{5}$. On the one hand, analyzing from the sign of the parameter, if the parameter estimation is positive and its significance can be proved by $t$-test, it shows that the independent variable of this parameter is positively correlated to the increase of $D A_{i, t}$; instead, if the result of parameter estimation is negative and the significance can be proved by $t$-test, it shows that the independent variable of this parameter does not promote the increase of
$D A_{i, t}$. On the other hand, we can determine the different earnings management preferences by comparing the absolute value of each parameter. The larger absolute value shows that the independent variable has a greater influence on the discretional accruals, and the possibility of adjusting accruals through these indicators is relatively large; on the contrary, the smaller absolute value indicates that the effect of the independent variable on the discretional accruals is lower. Based on the above two aspects of analysis, we can get some characteristics of electricity listed companies in the use of earnings management methods.

Using software to analyze the financial data of electricity listed companies from 2014 to 2016 year by year, the test results are obtained in Table 11.

TABLE 11: TEST OF MULTIVARIATE LINEAR REGRESSION MODEL

\begin{tabular}{lcccc}
\hline year & r-square & adjusted r-square & F value & P value \\
\hline 2014 & 0.652 & 0.643 & 20.561 & 0.059 \\
2015 & 0.850 & 0.821 & 17.812 & 0.021 \\
2016 & 0.793 & 0.774 & 22.039 & 0.008 \\
\hline
\end{tabular}

It can be seen from the above test results that the original $R^{2}$ value and the adjusted $R^{2}$ value reflect the well goodness of fit of the model and it can be used as a fitting test of the earnings management methods. The independent variables in the sample can be a better explanation of the dependent variable to a certain degree. $F$ value is also more significant, indicating that there is a certain linear relationship between the various earnings management methods and final accruals; $\mathrm{P}$-value test results show that the independent variables have a higher significant level on discretional accruals. Overall, the multivariate linear regression model established earlier can be used to analyze the earnings management methods of electricity listed companies.

The following is the parameter estimation of the corresponding coefficient of each variable, and the results are given in Tables 12 to 14 .

It can be seen from the above parameter estimation that the coefficient values corresponding to constant, investment income, and operating cash flows fluctuate between positive and negative, and the sign is not fixed in different years. For example, the corresponding coefficient estimation of investment income is changed from -0.2017 in 2014 to a positive value of 0.2875 in 2015, and then is negative of 0.0032 in 2016, its absolute value has been always small, indicating that its impact on profit is small, and the direction of adjustment is uncertain. The earnings management methods of operating cash flows and non-operating income and expenditures are similar to the above. To a certain extent, this also reflects the uncertainties and frequent changes in the use of investment tools, operating cash flows and nonoperating income and expenditures for earnings management of electricity listed companies. 
TABle 12: Parameter estimation of the VARiables COEFFicient In 2014

\begin{tabular}{|c|c|c|c|c|c|}
\hline variables & coefficient & estimation & standard deviation & $t$ value & $P$ value \\
\hline constant & $\alpha_{0}$ & 0.0032 & 0.0142 & -6.2433 & 0.0542 \\
\hline fixed assets (FA) & $\alpha_{1}$ & 0.0483 & 0.0089 & 2.3379 & 0.0081 \\
\hline impairment of assets (IOA) & $\alpha_{2}$ & 0.0392 & 0.0328 & 5.0186 & 0.0296 \\
\hline investment income (IVT) & $\alpha_{3}$ & -0.2017 & 0.0446 & -0.9277 & 0.0045 \\
\hline operating cash flows (CFO) & $\alpha_{4}$ & 0.0103 & 0.1832 & 3.0015 & 0.0791 \\
\hline non-operating income and expenditure (NOI) & $\alpha_{5}$ & -0.0859 & 0.0019 & -0.0089 & 0.0658 \\
\hline
\end{tabular}

Table 13: Parameter estimation of the VAriables COEFFicient IN 2015

\begin{tabular}{|c|c|c|c|c|c|}
\hline variables & coefficient & estimation & standard deviation & $t$ value & $P$ value \\
\hline constant & $\alpha_{0}$ & 0.0652 & 0.0901 & -7.3718 & 0.0071 \\
\hline FA & $\alpha_{1}$ & 0.1082 & 0.0073 & 4.3189 & 0.0911 \\
\hline IOA & $\alpha_{2}$ & 0.5984 & 0.0031 & 3.7913 & 0.0033 \\
\hline IVT & $\alpha_{3}$ & 0.2875 & 0.0932 & 5.8944 & 0.0982 \\
\hline $\mathrm{CFO}$ & $\alpha_{4}$ & -0.7811 & 0.1383 & 0.7931 & 0.0659 \\
\hline NOI & $\alpha_{5}$ & -0.3281 & 0.0089 & -6.3194 & 0.1039 \\
\hline
\end{tabular}

TAble 14: Parameter estimation of the Variables Coefficient In 2016

\begin{tabular}{|c|c|c|c|c|c|}
\hline variables & coefficient & estimation & standard deviation & $t$ value & $P$ value \\
\hline constant & $\alpha_{0}$ & -0.2872 & 0.0034 & 10.3193 & 0.0004 \\
\hline FA & $\alpha_{1}$ & 0.6292 & 0.0831 & 8.8919 & 0.0310 \\
\hline IOA & $\alpha_{2}$ & 0.5721 & 0.0003 & 5.3178 & 0.0249 \\
\hline IVT & $\alpha_{3}$ & -0.0032 & 0.3100 & 6.9001 & 0.1039 \\
\hline $\mathrm{CFO}$ & $\alpha_{4}$ & -0.0548 & 0.9410 & -4.4289 & 0.2894 \\
\hline NOI & $\alpha_{5}$ & -0.2910 & 0.1093 & -7.8136 & 0.0698 \\
\hline
\end{tabular}

The corresponding parameter of fixed assets and asset impairment have been positive for three consecutive years and relatively stable, indicating that there is a positive linear relationship between these two items and the increase of discretional accruals. Taking the data in 2016 as an example, the corresponding coefficient of fixed assets is 0.6292, which is positive and has a relatively large absolute value, indicating that the fixed assets earnings management has a greater influence on the final discretional accruals. The standard deviation of 0.0831 is relatively small, $t$ value of 8.8919 exceeds the critical value, and the $p$ value is 0.0310 , these indicate that the results have a higher level of significance, and the sample data can better reflect the overall situation. Based on this, we can see that the electricity listed companies have certain preferences on fixed assets and asset impairment in their earnings management, and both of these factors have a great effect on the final discretional accruals. Of course, they also use some other earnings management methods to a certain extent, but the usage frequency and the direction of profit control are uncertain.

\subsubsection{Collinear diagnostics}

In order to further verify the reliability of the above results, this paper use SPSS software to make a collinear diagnostics of each variable and further identify the significance level of the model. It proved that each variable has an independent influence on the final discretional accruals, not by the influence of other independent variables which have approximate linear relations with each other, and avoided the instability of the model caused by the high correlation between multiple variables. The diagnostic results are shown in Table 15.

From the test results, it can be seen that the correlation among independent variables is more appropriate, there is no serious collinearity, and the significant level of the model is relatively good. Moreover, the independent variables in the model can better explain dependent variables which called discretional accruals.

\subsection{Conclusions}

This paper took the electricity listed companies as samples, and employed the statistical methods and empirical research methods to study the two main methods of fixed assets earnings management and asset impairment earnings management. The main conclusions are as follows:

(1) The electric power industry has the characteristics of high investment, high monopoly, intensive capital and 
Table 15: Collinear diagnostics

\begin{tabular}{|c|c|c|c|c|c|c|c|}
\hline \multicolumn{2}{|c|}{ Dimension } & 1 & 2 & 3 & 4 & 5 & 6 \\
\hline \multicolumn{2}{|c|}{ Eigenvalues } & 3.606 & 1.287 & 0.694 & 0.575 & 0.302 & 0.081 \\
\hline \multicolumn{2}{|c|}{ Conditional index } & 1.012 & 1.008 & 2.336 & 2.77 & 7.064 & 9.325 \\
\hline \multirow[t]{6}{*}{ Variance ratio } & Constant & 0.02 & 0.05 & 0 & 0.01 & 0.07 & 0.04 \\
\hline & FA & 0.08 & 0.1 & 0.07 & 0 & 0.04 & 0.2 \\
\hline & IOA & 0.24 & 0.71 & 0.05 & 0.26 & 0.59 & 0.03 \\
\hline & IVT & 0 & 0.12 & 0.48 & 0.72 & 0.31 & 0.89 \\
\hline & $\mathrm{CFO}$ & 0.78 & 0.03 & 0 & 0.34 & 0.18 & 0.06 \\
\hline & NOI & 0.01 & 0 & 0.02 & 0.01 & 0.04 & 0.23 \\
\hline
\end{tabular}

technology, large proportion of fixed assets to the total assets, and a large capital chain. Coupled with the impact of the revision of the two rounds of accounting standards in 2006 and 2014 on the earnings management environment of listed companies, we can see that among various methods of earnings management, the electricity listed companies have certain tendencies and preferences on the two earnings management methods of fixed assets and asset impairment.

(2) Through the collection and analysis of the financial data of 52 electricity listed companies in Shanghai Stock Exchange and Shenzhen Stock Exchange, we found that most of the change rates of fixed assets depreciation expenses are at the range of 0 to $30 \%$, the ratio of bad debt provision to receivables are controlled at $5 \%$, the ratio of the inventory provision to total inventory are controlled at $20 \%$. The companies who exceed the above threshold is very few, and these companies are probably have earnings management in the above two items.

(3) Through the empirical research on earnings management methods of listed companies in electric power industry, it is found that there is a positive linear relationship between fixed assets management, asset impairment management and discretional accruals, and the degree of influence is more obvious and stable than that of other earnings management methods, and passed the test of significance. The collinear diagnostics can also prove a more reasonable correlation among the variables, indicating that the results obtained from the modified Jones model is more significant.

\subsection{Conflicts of interest}

We declare that there is no conflict of interest regarding the publication of this article.

\section{0 Acknowledgements}

This work is supported by "the Fundamental Research Funds for the Central Universities (2017MS199)".

\section{0 References}

[1] William R. Scott (19\&\&): "Financial Accounting Theory", Prentice Hall.

[2] Zheng Sun and Yuetang Wang (1999): "Empirical Study on Resource Allocation and Earnings Manipulation", The Study of Finance and Economics, (4), p.3-9.

[3] Rongsheng Qin (2001): "A New Topic of Financial Accounting: Earnings Management", Contemporary Finance and Economics, (2), p.55-60+80.

[4] Katherine Schipper (1989): "Commentary on Earnings Management", Accounting Horizons, Vol.3 (4), p.91-102.

[5] Healy, Paul M., Wahlen and James M, (1999): "A Review of the Earnings Management Literature and Its Implications for Standard Setting", Accounting Horizons, Vol.13 (4), p.365-383.

[6] Weidong Zhang, (2010): "Private Placement of New Shares and Earnings Management - Empirical Evidence from China's Securities Market", Management World, (1), p.54-63+73.

[7] Zhengfei Lu and TaoWei, (2006): "Declining Performance after Stocks Allotment: Earnings Management Consequences and Real Performance Decline", Accounting Research, (8), p.52-59+97.

[9] Deangelo and Linda Elizabeth,(1988): "Managerial Competition, Information Costs, and Corporate Governance: The Use of Accounting Performance Measures in Proxy Contests", Journal of Accounting and Economics, Vol.10 (1), p.3-36.

[9] Patricia M. Dechow and Richard G. Sloan,(1991): "Executive Incentives and the Horizon Problem: An Empirical Investigation", Journal of Accounting and Economics, Vol.14 (1), p.51-89.

[10] Sugata Roychowdhury, (2006): "Earnings Management through Real Activities Manipulation", Journal of Accounting and Economics, Vol.42 (3), p.335-370.

(Continued on page 100) 